\begin{tabular}{|c|c|c|}
\hline institute & $\begin{array}{l}\text { CARADDE: Jurnal Pengabdian Kepada Masyarakat } \\
\text { https://journal.ilininstitute.com/index.php/caradde } \\
\text { Volume 1 | Nomor 2 | Februari | 2019 } \\
\text { e-ISSN: } 2621-7910 \text { dan p-ISSN: } 2621-7961 \\
\text { DOI: } \text { https://doi.org/10.31960/caradde.v1i2.73 }\end{array}$ & $\begin{array}{l}\text { IUiN } \\
\text { CARADDE } \\
\end{array}$ \\
\hline
\end{tabular}

\title{
Pendidikan dan Pemberdayaan Masyarakat Berbasis Home Industri Ikan Lele Asap
}

\section{Hadi Pajarianto}

\section{Keywords :}

Diversifikasi;

Pendidikan, Pemberdayaan, Home

Industri, Ikan Lele.

\section{Corespondensi Author}

Prodi Pendidikan Guru PAUD, STKIP

Muhammadiyah Palopo Kec. Wara

Selatan Kota Palopo

Email: pajariantohadi@gmail.com

\section{History Artikel}

Received: tgl-bln-thn; Reviewed: tgl-bln-thn Revised: tgl-bln-thn Accepted: tgl-bln-thn Published: tgl-bln-thn
Abstrak. Tujuan artikel pendidikan dan pemberdayaan masyarakat berbasis home industri ikan lele asap adalah kegiatan pengabdian yang dilaksanakan sebagai bentuk keresahan akademisi akan pemanfaatan ikan lele sebagai sumber makanan yang sangat kaya gizi, masih sebatas konsumsi ikan lele segar, dengan ketahanan untuk di konsumsi sangat terbatas. Permasalahan yang dialami oleh mitra adalah: (1) belum memiliki teknologi proses yang memadai; (1) belum memiliki Brand dan desain kemasan produk agar familiar; (3) belum memiliki desain label yang menarik; dan (4) lemahnya manajemen produksi dan manajemen pemasaran. Strategi yang digunakan untuk penyelesaian masalah adalah dengan: (1) meningkatkan pemahaman mitra tentang manajemen usaha terutama yang berkaitan dengan optimalisasi manajemen sumber daya manusia; (2) meningkatkan pemahaman mitra tentang rumusan dan manfaat perencanaan bisnis (bussines plan); (3) meningkatkan Brand melalui desain kemasan dan produk; (4) meningkatkan pemahaman mitra tentang manajemen keuangan, (5) meningkatkan pemahaman dan keterampilan mitra tentang proses produksi dengan menggunakan alat yang lebih canggih; dan (6) menghasilkan proposal untuk diajukan memperoleh dana dari pemerintah maupun dari swasta baik berupa hibah, seperti program Kelompok Usaha Pemuda Produktif (KUPP) dan Kelompok Wirausaha Desa (KWD) dari Ditjen FNPI serta dari pemerintah daerah atau berupa pendanaan dalam bentuk kredit dari perbankan maupun dari BUMN non bank.

\section{PENDAHULUAN}

Pendidikan kewirausahaan saat ini telah dikembangkan hampir di semua perguruan tinggi di Indonesia dengan proses dan cara yang sangat bervariasi, bertujuan untuk menciptakan wirausaha. Wirausaha adalah seseorang yang dengan kreativitasnya menciptakan sesuatu yang memiliki values, baik dalam bentuk tangible maupun intangible
(Susilaningsih, 2015). Proses tersebut dapat dilakukan di dalam perusahaan yang diciptakan sendiri maupun di dalam organisasi tempat seseorang bekerja sesuai keahliannya. Pendidikan kewirausahaan adalah aktivitas pengajaran dan pembelajaran tentang yang meliputi pengembangan pengetahuan, ketrampilan, sikap dan karakter pribadi sesuai dengan umur dan perkembangan peserta didik tentang 
kewirausahaan (Kusmintarti, Riwajanti , \& Asdani, 2017)

Selain pendidikan, kewirausahaan juga dapat ditransformasikan kepada masyarakat melalui kegiatan pemberdayaan masyarakat. Pemberdayaan sebenarnya tujuannya sama dengan pendidikan, yakni memberdayakan potensi yang dimiliki oleh masyarakat. Kegiatan pemberdayaan dilakukan melalui serangkaian proses yang terukur dan terencana (Sofiah \& Sunarti, 2018). Perencanaan adalah proses yang sangat penting untuk dilakukan dalam pemberdayaan masyarakat, sebagai kerangka acuan bagi seluruh komponen yang terlibat di dalamnya. Sehingga, proses pengambilan keputusan benar-benar didasarkan pada tercapainya tujuan pembangunan (Mardikanto \& Soebiato, 2012). Salah satu pendekatan dalam pemberdayaan masyarakat adalah dengan model EPE (EngagementParticipation-Empowerment). Model EPE dalam proses pemberdayaan dimulai dengan keterlibatan (engangement), kemudian partisipasi (participation), yang keduanya menjadi prasyarat untuk mengembangkan masyarakat yang berdaya (empowerment) (Sofiah \& Sunarti, 2018).

Kota Palopo memiliki potensi yang sangat besar dalam produksi perikanan air tawar, seperti ikan lele, nila dan gurame. Khusus untuk ikan lele, program budidaya dan pemasaran ikan lele segar sudah dikenal oleh masyarakat Kota Palopo. Kondisi topografi Kota Palopo, kemampuan lele untuk mudah berkembang biak dan interest masyarakat dalam melakukan budidaya serta mengkonsumsinya akan menjadikan beberapa wilayah mampu berpotensi sebagai sentra pengembangan ikan lele. Namun produksi ikan lele dengan diversifikasi produk masih belum dilakukan secara profesional.

Diversifikasi produk tersebut sangat memungkinkan dilakukan sebagai salah satu upaya pemberdayaan ekonomi masyarakat Kota Palopo sekaligus peningkatan gizi dan ketahanan pangan. Daging ikan yang bersifat perishable food menjadikan suatu kendala untuk dilakukan penyimpanan dengan waktu yang lama. Pada suhu kamar, daging ikan yang tidak di olah lebih dari satu hari akan mudah mengalami pembusukan. Masyarakat pengkonsumsi daging ikan biasanya menyimpannya pada suhu di bawah $4 \mathrm{oC}$ bila ingin memanfaatkannya lebih dari satu hari.
Melalui proses pengolahan yang beragam untuk daging ikan dan pengkayaan kandungan gizi dengan penambahan bahan lain seperti rumput laut akan meningkatkan daya jual produk yang dihasilkan.

Pemanfaatan daging ikan lele sebagai sumber makanan bergizi di Kota Palopo hanya sebatas konsumsi ikan lele segar dengan harga hanya sekitar Rp.11.000,hingga Rp.12.000,- per kg dengan ketahanan daging ikan lele segar untuk di konsumsi sangat terbatas (rentang waktu maksimal 2 hari). Distribusi peternak lele di Kota Palopo meliputi wilayah Kecamatan Wara Selatan, Bara, dan Wara Timur, dengan jumlah produksi yang masih terbatas, tetapi memiliki potensi untuk ditingkatkan. Sebagian masyarakat Palopo juga masih belum familiar dengan masakan ikan lele, bahkan ada yang menganggap sebagai hewan predator pemakan segala, sehingga enggan untuk menjadikannya sebagai makanan yang kaya gizi. Padahal, ikan lele dapat didiversifikasi menjadi olahan yang variatif, seperti lele asap, dendeng lele, dan kerupuk tulang lele yang memiliki cita rasa tinggi serta memenuhi nilai estetik ketika dihidangkan.

Ikan lele (Clarias gariepinus) merupakan salah satu komoditas perikanan yang cukup populer di masyarakat. Ikan ini berasal dari benua Afrika dan pertama kali didatangkan ke Indonesia pada tahun 1984. Lele dumbo termasuk ikan yang paling mudah diterima masyarakat karena berbagai kelebihannya. Kelebihan tersebut diantaranya adalah pertumbuhannya cepat, memiliki kemampuan beradaptasi terhadap lingkungan yang tinggi, rasanya enak dan kandungan gizinya cukup tinggi serta harganya murah. Komposisi gizi ikan lele meliputi kandungan protein $(17,7 \%)$, lemak $(4,8 \%)$, mineral (1,2\%), dan air (76\%) (Ubadillah \& Hersoelistyorini, 2010).

Keunggulan ikan lele dibandingkan dengan produk hewani lainnya adalah kaya akan leusin dan lisin. Leusin $\left(\mathrm{C}_{6} \mathrm{H}_{13} \mathrm{NO}_{2}\right)$ merupakan asam amino esensial yang diperlukan untuk pertumbuhan anak dan menjaga keseimbangan nitrogen. Leusin juga berguna untuk perombakan dan pembentukan protein otot. Sedangkan lisin merupakan salah satu dari 9 asam amino esensial yang dibutuhkan untuk pertumbuhan dan perbaikan jaringan. Lisin termasuk asam amino yang sangat penting dan dibutuhkan 
Caradde: Jurnal Pengabdian Kepada Masyarakat

Vol 1 No 1, Agustus 2018

sekali dalam pertumbuhan dan perkembangan anak.

Berdasarkan dari latar belakang tersebut, mitra dalam kegiatan ini adalah bapak Muhammad Rum salah satu tokoh dan aktivis pertanian yang menginisiasi dan mendirikan Pusat Pelatihan Pertanian dan Perdesaan Swadaya di kelurahan Songka. Sedangkan mitra kedua adalah Klinik St. Khadijah Aisyiyah sebagai pendistribusi olahan ikan lele bagi ibu hamil yang datang berkunjung, serta Koperasi Civitas Akademika Perguruan Tinggi Muhammadiyah untuk memasarkan produk olahan ikan lele kepada masyarakat luas.

Alasan memilih 3 (tiga) mitra ini karena keuletan dan pengalaman mitra dalam membuat dan memasarkan produk kreatif aneka olahan ikan lele, sehingga masih eksis sampai saat ini. Alasan lainnya adalah untuk menyokong Home Industri sebagai kiat berwirausaha sehingga membantu program pemerintah dalam menciptakan lapangan pekerjaan. Kondisi usaha yang dialami oleh kelompok usaha ini memerlukan sentuhan dari pihak lain agar terjadi pengembangan usaha yang signifikan.

\section{METODE}

Kegiatan ini memanfaatkan pendekatan EPE yang secara proses merupakan keterkaitan dari tiga aktivitas, yakni; Engagement (keterlibatan), Participation (partisipasi), dan Empowerment (pemberdayaan). Sedangkan secara praktis, kegiatan dilakukan dengan menggabungkan konsep pendidikan (education), dan pemberdayaan (empowerment), sebagai berikut: 1. Motivasi wirausaha. Kegiatan ini diarahkan untuk membangun mindset wirausaha bagi mitra usaha sehingga dapat menumbuhkan motivasi wirausaha dan pengembangan usaha mitra. Kegiatan ini dilakukan dalam bentuk diskusi interaktif untuk mengungkap permasalahan dan potensi usaha yang dapat dikembangkan oleh mitra maupun kelompok usaha yang lainnya.
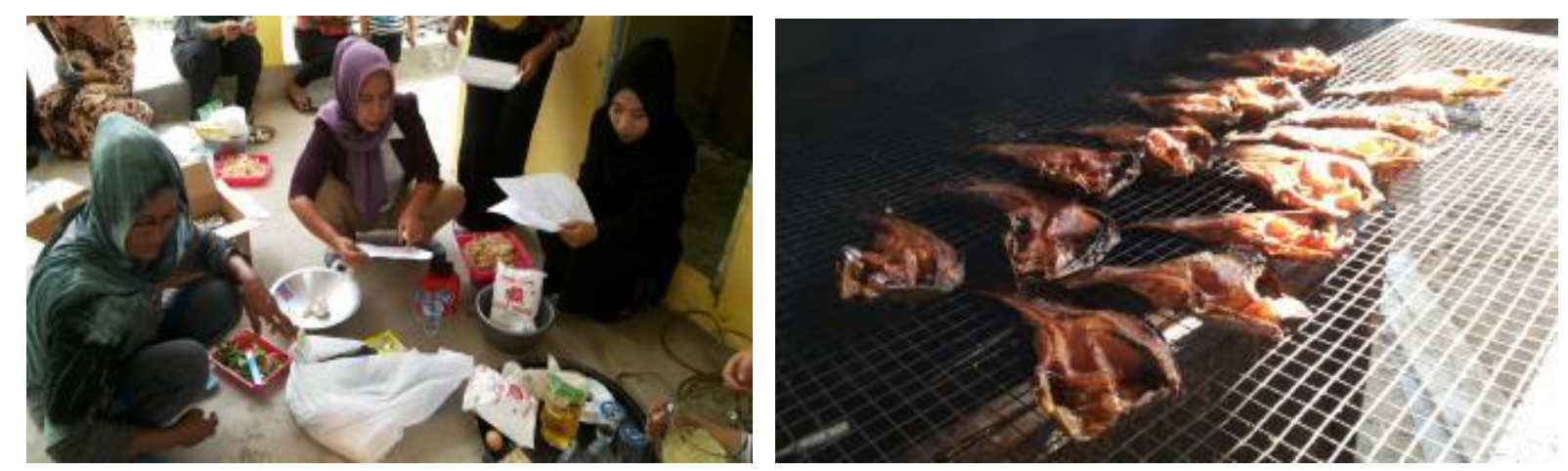

Gambar 1. Pelatihan Produksi Lele Asap bertempat di Pusat Pelatihan dan Pedesaan Swadaya (P4S) Kelurahan Songka

2. Pelatihan manajemen usaha. Kegiatan ini dilakukan dalam rangkaian kegiatan Enterpreneurship Motivation. Fokus dari materi ini adalah menambahnya wawasan tentang strategi merintis dan mengembangkan usaha bagi baik secara umum maupun secara khusus yang berkaitan dengan jenis usaha yang sedang digeluti.

3. Pendampingan penyusunan rencana bisnis. Rencana bisnis merupakan bagian penting dari upaya pengembangan bisnis.

Sebagian wirausaha menganggap rencana bisnis tidaklah terlalu penting sepanjang kita tidak memerlukan sumber pendanaan dari pihak lain. Pelatihan dan pendampingan pembuatan rencana bisnis difokuskan untuk memberikan wawasan pengembangan bisnis serta dapat menghasilkan rencana dan bisnis yang sedang dikembangkan. Rencana bisnis akan digunakan untuk mengakses sumber pendanaan baik dari bank maupun non bank. 
Hadi Pajarianto, Pendidikan dan Pemberdayaan Masyarakat Berbasis Home Industri Ikan Lele Asap

4. Pendampingan manajemen keuangan. Kemapuan kelompok wirausaha dalam merancang laporan keuangan sangat diperlukan agar proses pelaksanaan bisnis bisa berjalan dengan efektif. Laporan keuangan dengan standar akuntansi mungkin tidak terlalu mendesak diperlukan bagi wirausahawaan pemula. Tetapi kemampuan pengelolaan keuangan sangat diperlukan dalam kegiatan bisnis paling tidak dapat mencata arus kas dari proses usaha. Kegiatan ini dilaksanakan secara khusus untuk membina dan membekali kelompok usaha agar mampu mengelola keuangan. Dalam pelaksanaannya hanya seorang anggota kelompok usaha yang dilatih untuk dapat mengembangkan laporan keuangan.

5. Pengembangan uji coba produk. Untuk meningkatkan kemampuan produksi yang telah diperoleh, maka dilakukan latihan teknik produksi mulai dari tahap perencanaan sampai finishing. Pada kegiatan ini diikuti seluruh personil yang ada serta mahasiswa. Dari kegiatan ini diperoleh beberapa produk olahan ikan lele yang memiliki Brand identitas lokal masyarakat Luwu.

6. Pengembangan networking. Networking diperlukan untuk kepentingan ekspansi usaha. Melalui jejaring usaha yang dimiliki
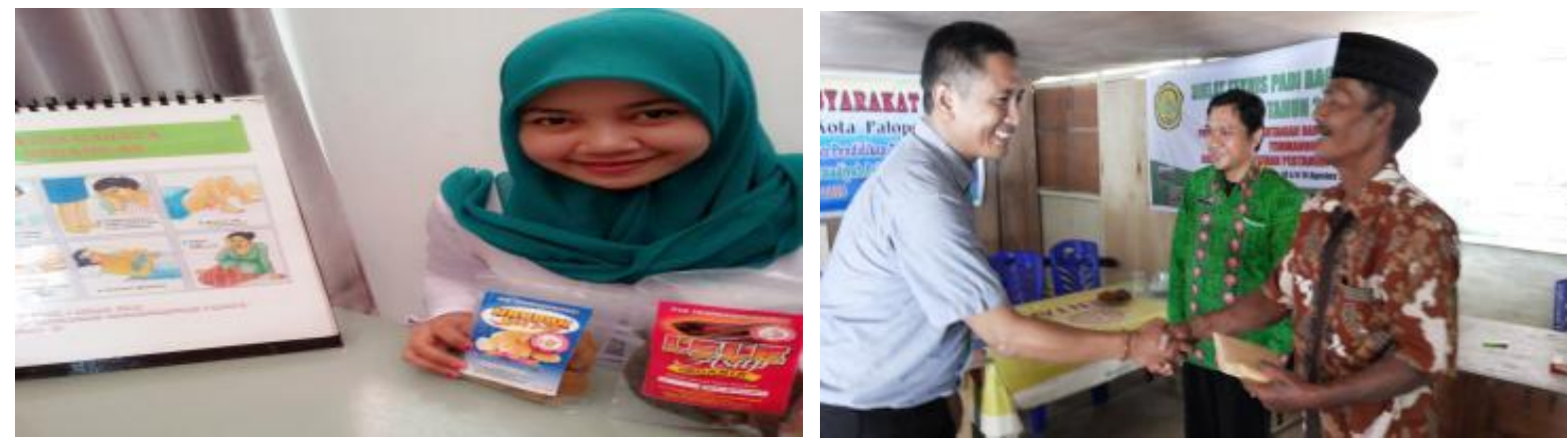

Gambar 3. Mahasiswa Kebidanan Memperkenalkan Manfaat Gizi Ikan Lele Asap, dan penyerahan bantuan modal

Meningkatnya motivasi berwirausaha pada mitra. Kegiatan ini diarahkan untuk membangun mindset wirausaha bagi mitra usaha sehingga dapat menumbuhkan motivasi wirausaha dan pengembangan usaha mitra. Kegiatan ini dilakukan dalam bentuk diskusi interaktif untuk mengungkap permasalahan dan potensi usaha yang dapat dikembangkan oleh mitra maupun kelompok usaha yang akan membantu proses promosi dan pemasaran. Kelompok usaha yang terbangun di sekitar kelompok usaha sangat kondusif meski menuntut persaingan.

\section{HASIL DAN PEMBAHASAN}

Kegiatan pendidikan dan pemberdayaan masyarakat berbasis kewirausahaan ikan lele dilaksanakan untuk memfasilitasi terbukanya lapangan kerja sehingga tingkat pengangguran dan kejahatan dapat diatasi, dengan demikian secara otomatis peningkatan pendapatan masyarakat pada kelompok mitra juga akan nampak. Masyarakat sekitar yang punya motivasi kerja dan tertarik pada dunia wirausaha tentu akan berusaha untuk mendapatkan informasi mengenai peluang yang dapat menghasilkan income. Salahsatunya adalah pengembangan produk olahan Ikan Lele Asap yang dapat menjadikan sarana untuk melakukan suatu usaha atau kegiatan pengolahan bahan mentah atau barang setengah jadi menjadi barang jadi. Barang jadi yang memiliki nilai tambah yang dapat memberi keuntungan. Dengan adanya keuntungan maka, kehidupan pun dapat berubah. Indikator capaian produk program yang telah direalisasikan dalam kegiatan ini adalah:

lainnya. Setelah mendapatkan materi praktis berwirausaha dan prospeknya. IKM Temangingi sebagai mitra utama dalam kegiatan ini yang pernah vakum selama satu tahun saat ini kembali beroperasi dengan merekrut 5 karyawan. IKM Temangingi dipimpin oleh bapak Muh. Rum di kelurahan Songka, pemilik usaha peternakan dan sampai pada pengolahan aneka produk ikan lele, bahkan saat ini tengah mempersiapkan 
modal agar produk olahan ikan lele dapaat diekspor. Motivasi berwirausaha juga terlihat dari antusiasme peserta yang dilatih sebanyak 15 orang.

Meningkatnya pengetahuan teknis petani terhadap teknologi pengolahan ikan Lele menjadi aneka olahan yang bergizi selain lele asap. Inovasi terhadap pengolahan ikan lele menjadi daya tarik tersendiri bagi karyawan IKM Temangingi untuk terus meningkatkan kualitas produksinya.

Meningkatnya pengetahuan kelompok binaan tentang manajemen Home Industri.

Pada awalnya, IKM Temangingi di desa Songka memproduksi secara sporadis ikan lele untuk konsumsi warga di sekitar Songka dan Kecamatan Wara Selatan. Melalui Program Ipteks bagi Masyarakat yang dibiayai oleh DP2M Dikti, kelompok binaan yang diberikan diberikan suntikan modal sebesar Rp. 8.000.000. Untuk keberlanjutannya, selain didampingi oleh dosen dan staf pada Laboratorium Kewirausahaan BPH PTM Muhammadiyah Palopo.

Meningkatnya jejaring pemasaran dan produksi Lele Asap. Dengan suntikan modal dan pelatihan yang diberikan oleh Tim Pengabdi, IKM Temangingi yang sempat vakum selama 6 (enam) bulan bangkit lagi untuk berproduksi. Saat ini, rata-rata dalam sebulan (per 01 September 2018), kelompok sasaran telah memproduksi sebanyak $300 \mathrm{~kg}$ ikan lele asap dan tulangnya dimanfaatkan untuk pembuatan kerupuk. Pemasaran yang pada awalnya masih berkisar di Kecamatan Wara Selatan, kini telah menjangkau di beberapa wilayah Kota Palopo. Koperasi Civitas Akademika PTM Palopo dan Klinik Siti Khadijah Aisyiyah milik AKBID Muhammadiyah Palopo. Pada umumnya konsumen tertarik mengkonsumsi Lele Asap karena gizi yang terkandung sangat baik untuk manusia. Jika dihitung, omset IKM Temangingi dalam sebulan dari produk olahan Lele Asap adalah sebesar Rp. 10.000.000,- dengan keuntungan sebesar Rp. 2.500.000,-. Hal ini dikarenakan mitra sempat vakum dan baru mulaia bangkit kembali atas suntikan dana dari program IbM. Dalam resesi ekonomi saat ini, tentu jumlah ini sangat membantu ibu-ibu yang menjadi karyawan dalam meningkatkan pendapatan keluarganya. Bahkan, melalui Lurah Songka dan Dinas Koperindag Kota Palopo difasilitasi pemasarannya menjangkau seluruh wilayah Kota Palopo dan Luwu Raya. Selain itu, pemasaran Lele Asap telah secara rutin dikonsumsi oleh mahasiswa PTM Palopo yang jumlahnya sekitar 1.700 orang, serta dosen dan civitas akademika.

Meningkatnya nilai estetika Brand/kemasan Lele Asap. Selama ini kemasan olahan Lele Asap dibuat sangat sederhana bahkan tradisional, karena terkadang hanya dengan kantongan plastik biasa. Program Ipteks bagi Masyarakat telah melatih masyarakat bagaimana membuat kemasan atau brand untuk produk olahan Lele Asap. Dengan pendanaan dari IbM, kelompok industri juga diberikan bantuan peralatan sederhana berupa alat-alat produksi dan vakum untuk ketahanan produk dalam kemasan. Kemasan yang dibuat saat ini sudah memenuhi aspek penting dalam pemasaran yang mencantumkan nama brand, rasa, berat, rasa, alamat pemesanan, dan nilai estetik lainnya yang dapat menarik konsumen.

Meningkatnya keterampilan mahasiswa sebagai sasaran antara yang strategis dalam mendesain program pemberdayaan masyarakat melalui program Ipteks bagi Masyarakat. Adanya keterlibatan langsung dari mahasiswa, maka dapat terbangun jaringan kerja dalam bentuk kelompok produksi usaha kecil dan membuka akses pemasaran melalui kemitraan dengan berbagai kelompok Home Industri yang dapat memacu jiwa kewirausahaan mahasiswa.

Mulai terlihatnya pola pemberdayaan kolaboratif antara Perguruan Tinggi dan masyarakat khususnya Home Industri Lele Asap di Kelurahan Songka melalui pendampingan dalam transfer keterampilan, modal dan akses pemasaran yang lebih luas.

Dihasilkannya pengalaman belajar yang nyata dalam pemberdayaan masyarakat yang berharga bagi mahasiswa dengan adanya keterlibatan dalam masyarakat secara langsung menemukan, merumuskan, memecahkan dan menanggulangi permasalahan pembangunan secara pragmatis dan interdisipliner.

\section{SIMPULAN DAN SARAN}

Kegiatan pendidikan dan pemberdayaan masyarakat berbasis kewirausahaan ikan lele 
Hadi Pajarianto, Pendidikan dan Pemberdayaan Masyarakat Berbasis Home Industri Ikan Lele Asap

asap, telah mampu meningkatkan pendapatan home industri rumah tangga, transfer teknologi sederhana, memperbaiki manajemen home industri, dan meningkatkan kemitraan antara masyarakat dan perguruan tinggi dalam memecahkan persoalan nyata yang dialami masyarakat. Masih diperlukan kegiatan evaluasi dan monitoring dilakukan secara menyeluruh mulai dari saat survey sampai pada saat berakhirnya kegiatan.

Salah satu indikator keberhasilan program pengabdian pendidikan dan pemberdayaan masyarakat berbasis home industri Ikan Lele Asap adalah keberlanjutan untuk jangka waktu yang panjang. Dari pantauan Tim, saat ini IKM Temangingi sebagai mitra utama telah bangkit dari kevakuman, dan memulai lagi memproduksi olahan ikan Lele Asap yang menjadi andalannya. Tim akan memfasilitasi akses kepada Pemerintah Kota Palopo yang saat ini sedang menggalakkan program Seribu Usahawan Baru melalui produk-produk lokal andalan.

\section{DAFTAR PUSTAKA}

Kusmintarti, A., Riwajanti , N. I., \& Asdani, A. (2017). Sikap Kewirausahaan Memediasi Pengaruh Pendidikan Kewirausahaan Terhadap Intensi Kewirausahaan. Jurnal Riset dan Aplikasi: Akuntansi dan Manajemen, 4554.
Mardikanto, T., \& Soebiato, P. (2012). Pemberdayaan Masyarakat dalam Perspektif Kebijakan Publik. Bandung: Alfabeta.

Sofiah, N., \& Sunarti. (2018). Proses Pemberdayaan dengan Model EPE (Engagement-Participation Empowerment) dalam Pembangunan Infrastruktur Desa Di Kabupaten Tegal). Jurnal Pengembangan Kota, 4555.

Susilaningsih. (2015). Pendidikan Kewirausahaan di Perguruan Tinggi: Pentingkah untuk semua profesi? . Economia , 1-9.

Ubadillah, A., \& Hersoelistyorini, W. (2010). Kadar Protein dan Sifat Organoleptik Nugget Rajungan dengan Substitusi Ikan Lele (Clarias gariepinus). Anas Ubadillah dan Wikanastri Hersoelistyorini Kadar Protein dan Sifat Organoleptik Nugget Rajungan dengan Substitusi Ikan Lele (Clarias gariepi, Jurnal Pangan dan Gizi, 45-54. 